\title{
Epstein-Barr Nuclear Antibody Measurement
}

National Cancer Institute

\section{Source}

National Cancer Institute. Epstein-Barr Nuclear Antibody Measurement. NCI Thesaurus.

Code C96603.

The determination of the amount of Epstein-Barr nuclear antibody present in a sample. 